\title{
PROBLEMATIKA GURU DALAM MENGAJARKAN PEMBELAJARAN SEJARAH DI MASA PANDEMI COVID-19
}

\author{
Mursidul Amin \\ Email: 1810111310005@mhs.ulm.ac.id \\ Program Studi Pendidikan Sejarah Fakultas Keguruan dan Ilmu Pendidikan \\ Universitas Lambung Mangkurat \\ Banjarmasin
}

\begin{abstract}
Abstrak
Problematika adalah suatu kesenjangan antara harapan dan kenyataan yang diharapkan dapat menyelesaikan atau dapat diperlukan atau dengan kata lain dapat mengurangi kesenjangan itu. sejarah sebagai ilmu dipelajari karena memiliki dua kegunaan, yaitu kegunaan instrinsik dan ekstrinksik. penguasaan IT bagi guru akan memberikan nilai tambah dalam proses pembelajaran dan secara otomatis akan memudahkan aktivitas guru itu sendiri. Untuk menumbuhkan minat belajar sejarah bagi siswa dalam kondisi pademi covid-19, maka guru harus berupaya agar suasana belajar tidak monoton, agar dapat membuat semua siswa tertarik dan semangat dalam mengikuti pembelajaran.
\end{abstract}

Keywords: problematika guru, pembelajaran sejarah, covid-19, minat belajar.

\section{PENDAHULUAN}

Menurut Debdikbud (dalam Muhith, A. 2018:47) Problematika berasal dari bahasa Inggris yaitu "problematic" yang artinya persoalan atau masalah, dalam kamus bahasa Indonesia, problema berarti hal yang belum dapat dipecahkan; yang menimbulkan permasalahan. Sedangkan menurut Syukir (dalam Pabumbun, A. R., \& Dalle, A. 2019:89) problema/problematika adalah suatu kesenjangan antara harapan dan kenyataan yang diharapkan dapat menyelesaikan atau dapat diperlukan atau dengan kata lain dapat mengurangi kesenjangan itu. Dari pemaparan yang telah dilakuka oleh kedua para ahli di atas dapat disederhanakan bahwa problematika merupakan masalah yang timbul akibat adanya kesenjangan antara harapan dan kenyataan sebagai suatu halangan pada sebuah proses (Pabumbun, A. R., \& Dalle, A. 2019:89).

Pendidikan Sejarah adalah suatu wahana penting dalam pendidikan suatu bangsa (Hasan, S. H. 2003). Suatu kenyataan yang tak dapat dipungkiri banyak negara di dunia ini yang menempatkan pendidikan sejarah sebagai unsur penting dalam pendidikan 
kebangsaan mereka. Kuntowijoyo (dalam Zaenal Arifin Anis, M. 2014:483) menjelasakan bahwa sejarah sebagai ilmu dipelajari karena memiliki dua kegunaan, yaitu kegunaan instrinsik dan ekstrinksik. Kegunaan instrinsik disini dimaksudkan adalah pelajaran sejarah yang dipelajari di jurusan sejarah yang terdapat di Fakultas Ilmu Kebudyaan, sedangkan ekstrinsik di pelajari pada jurusan Pendidikan Sejarah. Cahyono, Y. D. (2015:103) mengemukakan bahwa, Pembelajaran sejarah dikatakan baik jika proses pembelajaran mampu mengembangkan konsep generalisasi dan bahan abstrak dari peristiwa masa lampau dapat menjadi hal yang jelas dan nyata.

Heri, S. (2014:77) menjelaskan tujuan pembelajaran sejarah adalah siswa memahami dan menghayati nilai-nilai yang terkandung dalam setiap peristiwa sejarah, maka desain pembelajaran yang dibuat harus mampu mengungkapkan nilai-nilai tersebut sehingga mudah dipahami oleh peserta didik. Dalam jurnal Susanto, H. (2015:28) pembelajaran sejarah dengan tujuan melatih kemampuan siswa untuk berpikir historis merupakan upaya untuk menjadikan pembelajaran sejarah sebagai media pembentukan keterampilan akademis tingkat tinggi dan pembentukan sikap dan pola perilaku ilmiah.

Anis, M. Z. A. (2015:58) didalam artikelnya Menjelaskan bahwa Pembelajaran sejarah harus dilalui melalui tahapan, sebagai berikut: (1) memupuk kesadaran sosial dan keakraban, (2) memperkenalkan makna dimensi waktu dalam dinamika kehidupan kepada siswa dan rasa hayar sejarah. Materi pelajaran sejarah jangan didominasi oleh sejarah politik melainkan sejarah sosial yang berisikan kreativitas lokal. Pada tahap ketiga sejarah diajarkan sebagai kegiatan akademis untuk memahami jiwa dari sebuah perubahan.

Pandemi covid-19 secara tiba-tiba dengan cepat menyebar keseluruh dunia dan berdampak buruk terhadap bidang ekonomi, bidang sosial dan tak terkecuali bidang pendidikan. Menurut Ahmad et al (dalam Herliandry, L. D.et al 2020:67) menjelasakan kondisi saat ini mendesak untuk melakukan inovasi dan adaptasi terkait pemanfaatan teknologi yang tersedia untuk mendukung proses pembelajaran. Pembelajaran online menjadi langkah yang paling efektif untuk meminimalisir penyebaran wabah pada peserta didik dan pendidik. Menurut Gunawan et al (dalam Herliandry, L. D.et al 2020:67) pembelajaran online dapat memanfaatkan platform berupa aplikasi, website, jejaring sosial maupun learning management system. Dengan menggunakan platform tersebut dapat 
dimanfaatkan untuk mempermudah pembelajaran baik dalam hal memberikan informasi dan perbaikan dari kebijakan yang dilakukan.

\section{KESIAPAN GURU SEJARAH DALAM MENGHADAPI PANDEMI COVID-19}

Kebijakan social distancing maupun physical distancing guna meminimalisir penyebaran Covid-19 mendorong semua elemen pendidikan untuk mengaktifkan kelas meskipun sekolah tutup. Tentunya hal tersebut memberikan tantangan tersendiri bagi para guru untuk mempersiapkan pembelajaran secara daring. Menurut Darmalaksana dkk (dalam

Fajriana, F., \& Safriana, S. 2021 :294) pembelajaran daring terbukti efektif dilaksanakan pada masa belajar dari rumah akibat pandemic Covid-19.

Dalam mengimplementasikan pembelajaran daring, tentunya guru memegang peranan yang sangat penting dalam pembelajaran. Guru dituntut harus mampu menguasai ilmu teknologi khususnya dalam pembelajaran daring sehingga proses pembelajaran dapat berjalan dengan lancar. Menurut Imania \& Bariah (dalam Fajriana, F., \& Safriana, S. 2021:294) penguasaan IT bagi guru akan memberikan nilai tambah dalam proses pembelajaran dan secara otomatis akan memudahkan aktivitas guru itu sendiri. Guru dapat memanfaatkan berbagai media yang tersedia, seperti Zoom, Google Meet, Google Classroom dan platform lainnya yang dapat dioptimalkan dalam pembelajaran daring. Melalui media terebut, guru dapat mebagikan pengetahuan dan keterampilannya. Sehingga dengan kondisi pandemi seperti sekarang ini guru dituntut harus lebih kreatif, inovatif dan memanfaatkan media pembelajaran secara daring dalam menyiapkan proses pembelajaran bagi siswa.

Kesiapan dalam pelaksanaan pembelajaran secara daring di pengaruhi oleh beberapa faktor. Menurut Prabowo, A. S. dkk (2020:11) dalam penelitiannya menguraikan beberapa faktor yang mempengaruhi pembelajaran secara online : faktor pertama adalah tidak efektifnya pelatihan yang dilakukan di sekolah. Faktor kedua yang mempengaruhi kesiapan guru dilapangan untuk melaksanakan pembelajaran secara daring adalah guru yang merasa belum percaya diri dapat mengekspresikan berbagai emosi dalam media virtual. Faktor selanjutnya adalah Self-Directed Learning. Beberapa indikator yang menunjukan lemahnya SDL pada guru adalah kesulitan mengatur waktu karena harus 
mengajar dari rumah, terganggu oleh aktivitas online lainnya saat sedang mengajar, tidak memiliki optimisme dalam menggunakan aplikasi pembelajaran daring, serta tidak mampu menikmati tantangan baru dalam pekerjaan.

\section{MENUMBUHKAN MINAT BELAJAR SEJARAH PADA MASA PANDEMI COVID-19}

Yunitasari, R., \& Hanifah, U. (2020:236) menjelasakan Minat belajar adalah salah satu faktor yang sangat penting untuk keberhasilan belajar yang dimiliki siswa, minat muncul dari dalam diri siswa itu sendiri. Sedangkan menurut Ricardo \& Meilani (dalam Yunitasari, R., \& Hanifah, U. 2020:236) Minat belajar adalah suatu rasa untuk menyukai atau juga tertarik pada suatu hal dan aktivitas belajar tanpa ada yang menyuruh untuk belajar. Minat belajar menjadi faktor pendorong untuk siswa dalam belajar yang didasari atas ketertarikan atau juga rasa senang kepada pelajaran yang akan diajarkan.

Menurut Eberly Center (dalam Ricardo, R., \& Meilani, R. I. 2017:191) minat belajar dapat ditingkatkan dengan tujuh langkah, yaitu :

Yang pertama, dengan mengartikulasikan tujuan pembelajaran. Yang kedua, dengan membuat relevansi antara materi pembelajaran dengan kehidupan akademik siswa. Yang ketiga, dengan menunjukkan relevansi materi ajar dengan kehidupan profesional siswa. Yang keempat, dengan menyoroti berbagai penerapan pengetahuan dan keterampilan di dunia nyata. Yang kelima, guru dapat menghubungkan pembelajaran dengan minat pribadi siswa. Yang keenam, memberikan kebebasan bagi siswa untuk membuat keputusan atau pilihan. Terakhir, guru dapat menunjukkan gairah dan sikap antusias untuk meningkatkan minat belajar siswa.

Susilo, A., \& Isbandiyah, I. (2019) menjelasakan didalam penelitiannya bahwa Permasalahan yang sering muncul dalam pendidikan sejarah sebelum pandemi Covid-19 adalah bahwa pembelajaran sejarah hanya diartikan sebagai transfer ilmu (transfer of knowledge), guru sejarah memiliki kecenderungan menyampaikan pengetahuan yang dimiliki oleh guru kepada peserta didik tentang ilmu sejarah, sementara itu makna yang ada dalam setiap peristiwa sejarah tidak dirasakan kebermanfaatannya oleh peserta didik. Fikri, A., \& Hasudungan, A. N. (2021:22) didalam penelitiannya berpendapat di masa pandemi Covid-19, permasalahan pendidikan semakin kompleks bukan saja soal metode dan 
konten/isi pembelajaran sejarah tetapi lebih dari ada masalah Pembelajaran Jarak Jauh (PJJ) yang tidak efektif. PJJ tidak efektif disebabkan yakni, sinyal dan kuota internet tidak mendukung, tidak semua peserta didik memiliki smartphone, psikologi peserta didik terganggu karena tidak berjumpa dengan teman sebaya, mulai bosan dengan PJJ dan lain sebagainya (Fikri, A., \& Hasudungan, A. N. 2021:22).

Untuk menumbuhkan minat belajar sejarah bagi siswa dalam kondisi pademi covid19, maka guru harus berupaya agar suasana belajar tidak monoton, agar dapat membuat semua siswa tertarik dan semangat dalam mengikuti pembelajaran. Guru harus menghilangkan anggapan bahwa pelajaran sejarah itu identik dengan metode hapalan. Guru harus berupaya mengembangkan model pembelajaran di saat masa pandemi seperti sekarang ini seperti penggunaan Power Point yang menarik, menampilkan video seputar sejarah agar siswa tidak mudah bosan saat belajar dan guru harus mampu membuat siswa aktif berinteraksi saat pembelajaran berlangsung.

\section{SIMPULAN}

Berdasarkan hasil telaah terhadap beberapa penelitian, maka dapat disimpulkan bahwa : problematika guru dalam mengajarkan pembelajaran sejarah dimasa pandemi covid-19 ini menjadi topik yang menarik untuk dibahas. Meski dalam kondisi yang serba terbatas karena pandemi, tetapi masih dapat melakukan pembelajaran dengan cara daring. Dalam pembelajaran daring tentunya guru lah yang berperan penting dalam kelancaran proses pembelajaran. Guru dituntut untuk bisa menguasai IT agar mudah dalam menerapakan pembelajaran berbasis daring. Selain dituntut untuk menguasa media pembelajaran berbasis daring guru juga di tuntut agar dapat menumbuhkan minat siswa dalam belajar sejarah. Menghilangkan anggapan bahwa pembelajaran sejarah itu monoton ataupun identik dengan metode hafalan dengan cara melakukan pembelajaran secara menarik mulai dari pembuatan power point yang menarik, disaat pembelajaran menampilkan video seputar sejarah ataupun dokumenter dan lain sebagainya. 


\section{REFERENSI}

Anis, M. Z. A. (2015). Sejarah Bukan Warisan Melainkan Pembelajaran.

Cahyono, Y. D. (2015). E-Learning (Edmodo) Sebagai Media Pembelajaran Sejarah. Jurnal Penelitian, 18(2).

Fajriana, F., \& Safriana, S. (2021). Analisis Kesiapan Guru Fisika dan Matematika dalam Pembelajaran Daring. Jurnal Pendidikan Sains Indonesia, 9(2), 293-304.

Fikri, A., \& Hasudungan, A. N. (2021). Analisis Kompetensi Dasar Esensial pada Mata Pelajaran Sejarah Indonesia di Masa Pandemi Covid-19. Indonesian Journal of Social Science Education (IJSSE), 3(1), 20-30.

Hasan, S. H. (2003). Problematika Pendidikan Sejarah. Bandung: FPIPS UPI.

Heri, S. (2014). Seputar Pembelajaran Sejarah; Isu, Gagasan Dan Strategi Pembelajaran. Aswaja Pressindo.

Herliandry, L. D., Nurhasanah, N., Suban, M. E., \& Kuswanto, H. (2020). Pembelajaran pada masa pandemi covid-19. JTP-Jurnal Teknologi Pendidikan, 22(1), 65-70.

Muhith, A. (2018). Problematika pembelajaran tematik terpadu di MIN III bondowoso. Indonesian Journal of Islamic Teaching, 1(1), 45-61.

Pabumbun, A. R., \& Dalle, A. (2019). Problematika Pembelajaran Kemampuan Menyimak Bahasa Jerman Siswa Kelas XI SMAN 11 Makassar. Eralingua: Jurnal Pendidikan Bahasa Asing dan Sastra, 1(2).

Prabowo, A. S., Conina, P. D. D., Afiati, E., \& Handoyo, A. W. (2020). KESIAPAN GURU DALAM MELAKSANAKAN PEMBELAJARAN DARING DITENGAH WABAH COVID-19. Jurnal Penelitian Bimbingan dan Konseling, 5(2).

Ricardo, R., \& Meilani, R. I. (2017). Impak minat dan motivasi belajar terhadap hasil belajar siswa. Jurnal Pendidikan Manajemen Perkantoran (JPManper), 2(2), 188201.

Susanto, H. (2015). Menghadirkan kelas Konstruktivis dalam Melatih Kemampuan berpikir Historis melalui model latihan Penelitian.

Susilo, A., \& Isbandiyah, I. (2019). Peran Guru Sejarah dalam Pembentukan Pendidikan Karakter Anak Era Globalisasi. Indonesian Journal of Social Science Education (IJSSE), 1(2), 171-180.

Yunitasari, R., \& Hanifah, U. (2020). Pengaruh Pembelajaran Daring terhadap Minat Belajar Siswa pada Masa COVID 19. Edukatif: Jurnal Ilmu Pendidikan, 2(3), 232243. 
Zaenal Arifin Anis, M. (2014). Sejarah, Pendidikan Sejarah, dan Pendidikan Karakter Dialog yang Tidak Pernah Dituntaskan. 